\title{
Improving survival of probiotic bacteria using bacterial poly-y-glutamic acid
}

Article

Accepted Version

Bhat, A. R., Irorere, V. U., Bartlett, T., Hill, D., Kedia, G., Charalampopoulos, D., Nualkaekul, S. and Radecka, I. (2015) Improving survival of probiotic bacteria using bacterial poly- $\gamma$ glutamic acid. International Journal of Food Microbiology, 196. pp. 24-31. ISSN 0168-1605 doi:

https://doi.org/10.1016/j.ijfoodmicro.2014.11.031 Available at https://centaur.reading.ac.uk/39037/

It is advisable to refer to the publisher's version if you intend to cite from the work. See Guidance on citing.

Published version at: http://dx.doi.org/10.1016/j.jijfoodmicro.2014.11.031

To link to this article DOI: http://dx.doi.org/10.1016/j.ijfoodmicro.2014.11.031

Publisher: Elsevier

All outputs in CentAUR are protected by Intellectual Property Rights law, including copyright law. Copyright and IPR is retained by the creators or other copyright holders. Terms and conditions for use of this material are defined in the End User Agreement.

\section{www.reading.ac.uk/centaur}

\section{CentAUR}


Central Archive at the University of Reading

Reading's research outputs online 


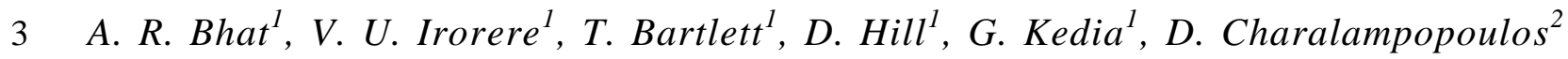

4 S. Nualkaekul ${ }^{2}$ and I. Radecka* ${ }^{1}$

5

$6{ }^{1}$ Faculty of Science and Engineering, University of Wolverhampton, WV1 1LY, United Kingdom;

$7 \quad{ }^{2}$ Department of Food and Nutritional Sciences, University of Reading, PO Box 226 White knights $8 \quad$ Reading RG6 6AP U.K.

$9 \quad \stackrel{*}{*}$ i.radecka@wlv.ac.uk, +441902322366

10 
A major hurdle in producing a useful probiotic food product is bacterial survival during storage and ingestion. The aim of this study was to test the effect of $\gamma$ PGA immobilisation on the survival of probiotic bacteria when stored in acidic fruit juice. Fruit juices provide an alternative means of probiotic delivery, especially to lactose intolerant individuals. In addition, the survival of $\gamma$-PGAimmobilised cells in simulated gastric juice was also assessed. Bifidobacteria strains (B. longum, B. breve), immobilised on $2.5 \% \quad \gamma$-PGA, survived significantly better $(\mathrm{P}<0.05)$ in orange and pomegranate juice for 39 and 11 days respectively, compared to free cells. However, cells survived significantly preparation, storage and ingestion of probiotic cells.

Keywords: Probiotics, $\gamma$-PGA, Bifidobacteria, fruit juice, simulated gastric juice. 


\section{INTRODUCTION}

The gastrointestinal tract (GIT) of humans is inhabited by a vast community of microbes representing well over 400 different microbial species, comprising $10^{14}$ bacterial cells which exceeds the number of eukaryotic cells in the human body by a factor of 10 (Cani and Delzenne, 2009; Turnbaugh et al., 2007). For proper functioning of the GIT, it is important to maintain a balance of the different organisms. This appears to be difficult due to various factors such as eating patterns, improper use of antibiotics and stress, all of which tend to favour the rise of pathogenic microorganisms and a decrease in beneficial microbes (Fooks and Gibson, 2002; McFarland and Dublin, 2008). Therefore, to maintain balanced microbial consortia in the GIT, beneficial organisms are often administered to individuals as 'probiotic organisms'. Probiotic organisms are defined as live organisms that confer health benefits to the host when administered in adequate amount (Reid et al., 2003). Most of the studied probiotic organisms include different strains of Lactobacillus and Bifidobacteria (Theodorakopoulou et al., 2013). There are numerous health and nutritional benefits of probiotic organisms including the promotion of healthy digestive system, prevention of urinary tract infection, prevention of cancer and promotion of immune response (Allaker and Douglas, 2009; Bertazzoni et al., 2013; Patel and Goyal, 2013; Prakash et al., 2011).

Although there is a lot of evidence in the literature on the benefits of probiotics, there remains an uncertainty about the usefulness of these bacteria. This uncertainty often stems from lack of reproducibility of the data, a possible consequence of insufficient/inconsistent numbers of live bacteria reaching the 
intestine. The benefits of probiotic bacteria are largely dependent on their ability to survive, colonize and multiply in the host (Anal and Singh, 2007; Burgain et al., 2011). It has been determined that a food with health claims from the addition of probiotics must contain at least $10^{6} \mathrm{CFU} / \mathrm{ml}$ of viable bacteria (Kailasapathy and Chin, 2000). Probiotics are usually administered or added to food products as dry cultures prepared mainly by freeze drying, as they are easier to handle when freeze dried. However, the procedures used to prepare freeze dried probiotic bacteria are detrimental to cell structure and viability (Saarela et al., 2005). Furthermore, the nature of the food or drink product into which the probiotic microorganism is introduced is generally limited to milk based products which maintain a weak acidic environment tolerated by the microorganisms. Even under these conditions, shelf life is still restricted. In addition, there is a considerable loss in viability of probiotic bacteria when they encounter the very acidic conditions of the stomach and high bile concentration in the small intestine. The mechanism of probiotic response to bile salt and stimulated gastric juice has previously been described (Sánchez et al., 2007; Sanchez et al., 2005). Therefore, there remains a need to improve the viability of probiotic microorganisms as they pass through the freeze drying, storage and ingestion processes.

Also, for individuals with lactose intolerance or milk protein allergy, it would be useful to broaden the range of products into which probiotic bacteria could be introduced, for example, fruit juices. Although fruit juices provide a less suitable environment for survival of probiotic bacteria (Saarela et al., 2006), which is most likely due to the low $\mathrm{pH}$ values of fruit juices compared to dairy products, 
the innovation of suitable technologies to improve bacterial survival in fruit juice will be a beneficial discovery. This will not only bring about an alternative to probiotic delivery to lactose intolerant individuals, but it may also help the bacteria to endure the harsh acidic conditions of the stomach, thus improving the survival of ingested probiotics.

Immobilisation and encapsulation of probiotic bacteria in different materials are present technologies used to improve the survival of probiotic cells during storage and ingestion. Although both terms (immobilisation and encapsulation) are often used interchangeably in literature, the latter refers to the formation of a continuous coating around an inner matrix wholly contained within the wall of the capsule, while the former involves trapping of the cells either within or throughout the matrix. In the former, a small part of the cell may be exposed at the surface while in the latter the cells are completely surrounded within a capsule (Kailasapathy, 2002; Vidhyalakshmi et al., 2009). Methods used for the immobilisation of probiotic cells include spray drying, freeze drying, extrusion and phase separation (Kailasapathy, 2002; Lozinsky et al., 2003; Vidhyalakshmi et al., 2009). Commonly used immobilisation materials include alginate, xanthan, carrageenan and phthalate cellulose (Doleyres and Lacroix, 2005). Although these materials have been shown to be useful in protecting cells during different stages of probiotic food preparation and ingestion, there remains the need to develop new materials which can protect cells not only during preparation, storage or ingestion but also throughout the process from preparation of the probiotic food product to its safe delivery to the host. 
1 We have earlier shown that immobilising probiotic bacteria in poly- $\gamma$-glutamic acid $(\gamma$-PGA) produced from a non-toxic microbial species of Bacillus can

3 improve the survival of these organisms during freeze drying (Bhat et al., 2013).

4 To continue with our investigation, this research was designed to study the 5 protective effect of $\gamma$-PGA on probiotic bacterial survival in two types of fruit 6 juices (orange and pomegranate juice) and in simulated gastric juice. Two $7 \quad$ Bifidobacterium strains were selected as model probiotic microorganisms for this 8 study, owing to their known susceptibility to low $\mathrm{pH}$ and various stress $9 \quad$ conditions (Russell et al., 2011). 


\section{MATERIAL AND METHODS}

\section{1 $\gamma-P G A$}

The sodium salt of $\gamma$-PGA (molecular weight $-257,000 \mathrm{Da}$ ) was produced using B. subtilis natto (ATCC 15245), following previously described methods (Kedia et al., 2010).

\subsection{Bacterial strains}

The probiotic bacterial strains used in this investigation were: Bifidobacterium longum NCIMB 8809 and Bifidobacterium breve NCIMB 8807. Strains were obtained from NCIMB as stock cultures and freeze-dried before storage at -20 ${ }^{\circ} \mathrm{C}$. Prior to their use, the cultures were revived aseptically and grown anaerobically on Bifidobacteria Selective Medium (BSM) Agar at $37{ }^{\circ} \mathrm{C}$ in jars using an atmosphere generation system (Oxoid Anaerogen ${ }^{\mathrm{TM}}$ ) and an indicator strip.

\subsection{Media}

BSM (a selective and differential media for Bifidobacteria) agar/broth were used for growth and enumeration of Bifidobacteria in simulated gastric juice (SGJ) experiment (Nualkaekul et al., 2011). BSM broth/agar were purchased and prepared according to the manufacturer's protocol (Sigma-Aldrich, U. K.). Phosphate buffered saline (PBS) obtained from Sigma-Aldrich was prepared by dissolving 1 tablet in $200 \mathrm{ml}$ following manufacturer's instructions.

SGJ contained $2 \mathrm{~g} / \mathrm{l} \mathrm{NaCl}, 3.2 \mathrm{~g} / \mathrm{l}$ pepsin powder and $20 \mathrm{ml}$ of $1 \mathrm{M} \mathrm{HCl}$ (British Pharmacopoeia Commission, 1993). The components were diluted in $900 \mathrm{ml}$ 
1 deionised water and after $\mathrm{pH}$ adjustment $(\mathrm{pH} 2.0)$, the volume was topped up to 1 1. $\mathrm{pH}$ was adjusted using $1 \mathrm{M} \mathrm{HCl}$ or $1 \mathrm{M} \mathrm{NaOH}$. This model solution was sterilized by passage through a sterile $0.2 \mu \mathrm{m}$ syringe filter.

\subsection{Preparation of $\gamma$-PGA-immobilised cells}

Freeze dried $\gamma$-PGA protected cells were prepared as described previously (Bhat et al., 2013). Cells were initially grown in BSM and recovered as pellets by centrifugation, and then washed with PBS and suspended in $10 \mathrm{ml}$ suspension of $10 \% \mathrm{w} / \mathrm{v} \gamma$-PGA. The cell $/ \gamma$-PGA suspension was then incubated at room temperature for $1 \mathrm{hr}$ and then at $-80^{\circ} \mathrm{C}$ for $24 \mathrm{hrs}$. Subsequently, the samples were freeze dried (Edwards Freeze Dryer, Modulyo, UK) at $-40{ }^{\circ} \mathrm{C}$ and $5 \mathrm{mbar}$ for 48 hrs (Bhat et al., 2013).

\subsection{Cell survival in fruit juices}

Fresh samples of commercially available orange juice (Tropicana orange juice, Pure Premium Smooth No Bits $-100 \%$ freshly squeezed orange juice) and pomegranate juice (POM Wonderful 100\% Pomegranate juice) were purchased from a local supermarket and used for the tests. No microbial growth was observed in overnight cultures of each juice at $37{ }^{\circ} \mathrm{C}$ under anaerobic conditions in BSM. The dry powder of $\gamma$-PGA-immobilised cells was suspended in $1 \mathrm{ml}$ PBS and this suspension was added to $40 \mathrm{ml}$ of the respective juice to give a final concentration of $\gamma$-PGA coated cells in fruit juice of $2.5 \%(\mathrm{v} / \mathrm{v})$. As control, nonimmobilised free cells were inoculated in BSM broth under the aforementioned conditions and the cell pellets were obtained after centrifugation and washing with PBS. The cell pellets were suspended in $1 \mathrm{ml}$ PBS and these cell 
suspensions (immobilised samples and control) were added to each juice and stored at $4{ }^{\circ} \mathrm{C}$. Samples were collected at day $0,2,4,6,8,11,13,20,28$ and 39 of storage for orange juice and at day $0,2,4,6,8,11$ and 13 for pomegranate juice. After appropriate dilution, $0.1 \mathrm{ml}$ aliquots from the dilutions were plated on BSM agar and incubated anaerobically at $37{ }^{\circ} \mathrm{C}$ for $48 \mathrm{hrs}$ to assess the concentration (expressed as $\mathrm{CFU} / \mathrm{ml}$ ) of the free and immobilised probiotic cells in the respective fruit juice.

\subsection{Organic acid concentration of fruit juice}

Organic acid analysis was performed using an Agilent 1100 HPLC system to assess any changes in the organoleptic composition of the fruit juice. A Prevail Organic Acid $5 \mu \mathrm{m}$ column with a UV detector was used for citric acid, malic

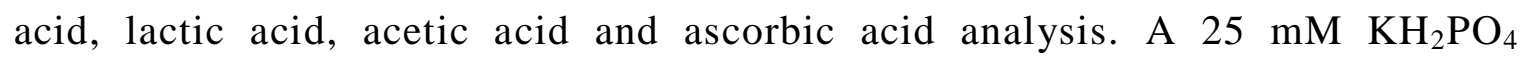
solution ( $\mathrm{pH} 2.5$ adjusted with phosphoric acid) was used as the eluent. Before loading, the samples were filtered using $0.45 \mu \mathrm{m}$ filters and diluted 10 fold with deionised water. Standard curves were prepared using known concentrations of the chemicals to be analysed.

\subsection{Probiotic survival in simulated gastric juice}

The survival of the two Bifidobacterium strains (free and immobilised on $\gamma$-PGA) in SGJ was monitored for $4 \mathrm{hrs}$.

The tests were carried out in an Electrotek Anaerobic Workstation, where a microaerophilic environment was maintained $\left(10 \% \mathrm{CO}_{2}\right.$ and $\left.5 \% \mathrm{O}_{2}\right)$ at $37{ }^{\circ} \mathrm{C}$. This would also test the effect of $\gamma$-PGA on the survival of bacteria when 
1 exposed to some oxygen just before ingestion. The cell concentration was measured at $0 \mathrm{hrs}, 1 \mathrm{hr}, 2 \mathrm{hrs}, 3 \mathrm{hrs}$ and $4 \mathrm{hrs}$ for $\gamma$-PGA-immobilised and free cell. This was done by making appropriate dilution of samples up to $10^{-8}$ and plating them out on BSM agar. Plates were incubated anaerobically at $37{ }^{\circ} \mathrm{C}$ for $48 \mathrm{hrs}$ to assess the cell concentration at different incubation times in SGJ.

\subsection{Statistical analyses}

All experiments were performed in triplicate and results were analysed using Microsoft Excel 2010 and Graph Pad Prism 5. Two-factor ANOVA was used to analyse the differences in survival of $B$. breve and B. longum in either juices with respect to time while Student's $\mathrm{T}$ tests were used to compare the acid concentration in the juices before and after treatment with immobilized and nonimmobilized probiotics. The Bonferroni multiple comparison test was used for non-parametric analysis of data to determine the difference between individual groups in a data set. A P. value $\leq 0.05$ was considered to be statistically significant.

\section{RESULTS}


$2.5 \% \gamma$-PGA-protected B. longum and B. breve were stored in orange juice for up to 39 days at $4{ }^{\circ} \mathrm{C}$. The results are presented in figures 1 and 2 along with the control experiments with non-immobilised free cells. After 13 days of storage, a loss in viable cell concentration of around $4.0 \log \mathrm{CFU} / \mathrm{ml}$ and $3.4 \log \mathrm{CFU} / \mathrm{ml}$ was observed in free B. breve and B. longum cells, respectively. A complete loss in viability of free cells in orange juice was observed on day 20 of the experiment for both strains. In contrast, $\gamma$-PGA-immobilised $B$. breve and $B$. longum cells showed only around $0.5 \log \mathrm{CFU} / \mathrm{ml}$ and $1.1 \mathrm{CFU} / \mathrm{ml} \log$ reductions in viable cells, respectively, after 13 days of storage at $4{ }^{\circ} \mathrm{C}$. On day 39 , viable counts of around $6.6 \log \mathrm{CFU} / \mathrm{ml}$ and $6.5 \log \mathrm{CFU} / \mathrm{ml}$ were observed for immobilised $B$. breve and B. longum cells respectively, indicating a reduction of approximately $2.1 \log \mathrm{CFU} / \mathrm{ml}$ and $3.2 \log \mathrm{CFU} / \mathrm{ml}$, respectively (Figures 1 and 2).

\section{2 $\gamma$-PGA protection of probiotic cells in pomegranate juice}

The results from the survival studies in pomegranate juice, carried out for up to 13 days of storage at $4{ }^{\circ} \mathrm{C}$, are presented in Figures 3 and 4 . A complete loss in viability for free B. longum cells was observed on day 6. In comparison, a complete loss in viability of free $B$. breve cells was observed on day 2. Another notable observation was a very low viable cell concentration of both free $B$. longum $(\sim 4.8 \log \mathrm{CFU} / \mathrm{ml})$ and B. breve $(\sim 5.0 \log \mathrm{CFU} / \mathrm{ml})$ cells on day 0 of the experiment, which indicates that a significant proportion of the cells died immediately after they were introduced into the juice. On the other hand, the 
immobilised cells survived considerably better in the pomegranate juice than the free cells. Nevertheless, a loss in viable cell concentration of around $2.9 \log$ $\mathrm{CFU} / \mathrm{ml}$ and $2.1 \log \mathrm{CFU} / \mathrm{ml}$ was observed for the $\gamma$-PGA-immobilised B. longum and $B$. breve cells after 2 days of storage, respectively. The cell concentration gradually declined until day 13 and day 11 with losses of around $5.5 \log \mathrm{CFU} / \mathrm{ml}$ for B. longum and $4.0 \log \mathrm{CFU} / \mathrm{ml}$ for $B$. breve, respectively. Both experiments were discontinued as the cell concentrations of both strains fell below the FAO recommended value of $6-7 \log \mathrm{CFU} / \mathrm{ml}$.

\section{3 pH and organic acid concentration of juices}

The $\mathrm{pH}$ of fresh orange juice, with no cells added was 3.91 (Table 1). This was reduced to 3.82 after 39 days of storage at $4{ }^{\circ} \mathrm{C}$. The $\mathrm{pH}$ of the orange juice containing free $B$. longum or B. breve was reduced to 3.71 and 3.65 , respectively, after 39 days of storage. On the other hand, the $\mathrm{pH}$ of the orange juice containing $\gamma$-PGA immobilised $B$. longum or B. breve increased to 4.36 and 4.22 , respectively, after 39 days storage (Table 1). For pomegranate juice, not much difference in the $\mathrm{pH}$ was observed between the fresh juice with no cells and juice containing free Bifidobacterium cells after 39 days of storage at $4{ }^{\circ} \mathrm{C}$. However, pomegranate juice containing $\gamma$-PGA immobilised cells showed an increase in $\mathrm{pH}$ of around 0.85 compared to fresh juice, resulting in a $\mathrm{pH}$ of around 4.05, after 39 days of storage.

Fresh orange juice, without the presence of Bifidobacterium cells, contained around $425 \mathrm{mg} / \mathrm{l}$ of ascorbic acid and this concentration dropped to around 161 $\mathrm{mg} / \mathrm{l}$ after storage at $4{ }^{\circ} \mathrm{C}$ for 39 days (Table 2). Orange juice with free B. longum 
and $B$. breve cells demonstrated a reduction in ascorbic acid concentration to around $79 \mathrm{mg} / \mathrm{l}$ and $173 \mathrm{mg} / \mathrm{l}$, respectively, after 39 days of storage. Likewise, orange juice containing $\gamma$-PGA-immobilised $B$. longum or $B$. breve cells demonstrated a reduction in ascorbic acid concentration to around $71 \mathrm{mg} / \mathrm{l}$ and $193 \mathrm{mg} / \mathrm{l}$, respectively, after 39 days of storage at $4{ }^{\circ} \mathrm{C}$ (Table 2).

The concentrations of citric acid and malic acid in the fresh orange juice were around $9.9 \mathrm{~g} / \mathrm{l}$ and $3.8 \mathrm{~g} / \mathrm{l}$ respectively. After 39 days of storage the difference in concentration of citric and malic acid in orange juice without Bifidobacterium cells was not significantly different when compared to that of fresh juice $(\mathrm{P}>$ 0.05). Similarly, in the orange juice with either free or $\gamma$-PGA immobilised $B$. longum or B. breve cells, there was no significant difference in the concentration of malic and citric acid compared to that of fresh juice $(\mathrm{P}>0.05)$ (Table 2).

The concentrations of citric, malic and ascorbic acids in pomegranate juice stored at $4{ }^{\circ} \mathrm{C}$ for 39 days are shown in Table 3. Contrary to the observations in orange juice, no reduction in the ascorbic acid concentration was observed in the pomegranate juice with free and $\gamma$-PGA-immobilised cells (Table 3). The concentration of citric and malic acid in the pomegranate juice with free and $\gamma$ PGA-immobilised cells did not show any significant $(\mathrm{P}>0.05)$ reduction either (Table 3).

\subsection{Protection of probiotic cells in simulated gastric juice}

The effect of $2.5 \% \gamma$-PGA immobilisation on the survival of $B$. longum and $B$. breve in simulated gastric juice (up to 4 hrs at $\mathrm{pH} 2$ ) was investigated in vitro and 
1 the data are presented in Figure 5. It can be seen that immobilisation protected the Bifidobacterium strains, as a marginal $(\sim 0.5 \log \mathrm{CFU} / \mathrm{ml})$ but not significant reduction in viable cell concentration after $4 \mathrm{hrs}(\mathrm{P}>0.05)$ was observed. In contrast, the free $B$. longum and $B$. breve cells showed a complete loss in viability within $2 \mathrm{hrs}$. Even after one hour in SGJ, the cell concentration of the free cells (around $4.0-4.2 \log \mathrm{CFU} / \mathrm{ml}$ for both Bifidobacterium cells) was below the recommended FAO values $\left(10^{6}-10^{7} \mathrm{CFU} / \mathrm{ml}\right)$ considered to be beneficial to the host.

4. DISCUSSION

Fruit juices are good candidates for the incorporation of probiotic bacteria, since they are rich in nutrients (Ding and Shah, 2008) and often have oxygen 
scavenging agents, such as ascorbic acid, which promote anaerobic conditions that are important for the survival of certain lactic acid bacteria and Bifidobacteria, commonly used as probiotics. In addition, fruit juices contain high amounts of sugars which could enhance the survival of the incorporated probiotic bacteria as they would serve as an energy source for maintenance of cellular activities (Delete). However, it is often seen that probiotic viability in fruit juices is hampered due to factors such as low $\mathrm{pH}$ and the presence of competing microorganisms (Granato et al., 2010). $\gamma$-PGA is a natural biopolymer that can be potentially incorporated into food as it is Generally Recognized As Safe (GRAS) by the FDA (Shyu and Sung, 2010) and has been shown from our previous research to have good cryoprotective properties for probiotic bacteria (Bhat et al., 2013). Among the various microorganisms used as probiotics, Bifidobacteria have attracted significant commercial interest over the years, as their beneficial health effects have been well documented, despite the fact that they are generally very sensitive to low $\mathrm{pH}$ conditions, either those in the food product or in the GIT (Cui et al., 2000). The aim of this work was to evaluate whether immobilisation of Bifidobacterium cells on $\gamma$-PGA, a GRAS polymer, can improve the survival of the cells in orange, pomegranate juice and simulated gastric juice.

In orange juice, free cells of both Bifidobacterium species, showed complete loss of viability within 20 days (Figure 1,2) with the number of cells going below the FAO value of $6-7 \log \mathrm{CFU} / \mathrm{ml}$ (Kailasapathy and Chin, 2000; Kurmann and Rasic, 1991) on day 11 (<5 log CFU/ml). In contrast, $\gamma$-PGA-immobilised cells survived well for 39 days in orange juice with viable cell concentrations of 6.48 

pomegranate juice, there was a complete loss in viable cell concentration of free B. longum cells within 6 days, with cell concentration reducing immediately upon introduction into the juice. This result was similar to that of $B$. breve, however, a complete loss in viability was observed after only 2 days of introducing free cells into the juice. This shows that $B$. longum survived better in pomegranate juice compared to $B$. breve. $\gamma$-PGA immobilised cells survived significantly better than free cells in pomegranate juice although not to the same extent as those in orange juice.

These results have clearly shown the bacterial protective ability of $\gamma$-PGA in fruit juices. Although the complete mechanism of protection within the juice is not fully understood, one possible explanation would be the physical entrapment of the cells to the polymer matrix. Also, it is possible that some of the $\gamma$-PGA may have solubilised over time in the juice, as a $\mathrm{pH}$ of $\sim 4.0$ has previously been shown to result in over $50 \%$ disruption of the $\alpha$-helical conformation of $\gamma$-PGA (Ho et al., 2006), thus leading to a higher $\mathrm{pH}$ level in both orange and pomegranate juice with $\gamma$-PGA-immobilized cells compared to juice with free cells or without any cells (Table 1). This increased $\mathrm{pH}$ may have created a better environment for the survival of the cells. However as the $\mathrm{pH}$ of the juice with $\gamma$ PGA-immobilized cells remained below 4.5, the $\mathrm{pH}$ change of $<1$ may not completely account for the increased survival as previous research has shown complete loss in cell growth of most probiotic cell at pH between 4.5 and 5.5 with cell death at $\mathrm{pH}$ of 4.1 or below (Shah and Dave, 2002). Thus, physical entrapment within the $\gamma$-PGA matrix as well as increase in the $\mathrm{pH}$ of the juice 
may both play important roles in the protection of probiotic cells in fruit juice by $\gamma$-PGA.

B. longum encapsulated in Ca-alginate beads has previously been shown to survive 6 weeks in orange juice with a reduction in viable cell number of $\sim 3.0$ $\log \mathrm{CFU} / \mathrm{ml}$ by the end of storage at $4{ }^{\circ} \mathrm{C}$ (Ding and Shah, 2008). In our experiment, $\gamma$-PGA immobilised cells showed a similar loss over a similar period. However, studies have shown that $\mathrm{Ca}$-alginate is not effective in protecting cells probiotic cells in juice when compared to polydextrose or sucrose. 
1 A more recent experiment by Nualkaekul et al,, showed that coating alginate bead encapsulated B. longum or L. plantorum with either chitosan, gelatin or glucomannan resulted in increased survival of the cells stored in either cranberry or pomegranate juice for 6 weeks at $4{ }^{\circ} \mathrm{C}$ (Nualkaekul et al., 2013). Depending on the coating material and the concentration used, they reported that a cell death of

6 less than 1 Log CFU/ml could be achieved (Nualkaekul et al., 2013). Although alginate bead coating resulted in increased cell survival in pomegranate juice when compared to $\gamma$-PGA, the process of encapsulation is more demanding when compared to the freeze drying process used in the production of $\gamma$-PGA immobilised cells. Also, the cost of encapsulation and coating are higher when in probiotic protection (Delete).

Comparing the Bifidobacteria survival results obtained from orange juice to that of pomegranate juice, it is clear that Bifidobacteria survived better in orange juice, with very poor survival recorded for unprotected Bifidobacteria cells in 
pomegranate juice. Also, B. longum survived significantly better $(\mathrm{P}<0.05)$ in pomegranate juice compared to $B$. breve. The poor survival of unprotected $B$. longum cells in pomegranate juice compared to orange juice has been demonstrated in other studies (Nualkaekul and Charalampopoulos, 2011; Nualkaekul et al., 2011), where B. longum viable cell concentration decreased by $\sim 8 \log \mathrm{CFU} / \mathrm{ml}$ and $\sim 0.8 \log \mathrm{CFU} / \mathrm{ml}$ in pomegranate and orange juice respectively within 1 week of storage at $4{ }^{\circ} \mathrm{C}$ (Delete). The poor survival of Bifidobacteria in pomegranate juice compared to orange juice may be due to its higher acidity most likely due to the much higher level of citric and malic acid (Tables 2 and 3). This high acidity which is likely to have resulted in the sharp decrease in viability may also be responsible for the lack of oxidation of ascorbic acid by the cells. Thus, no reduction in the acid content was observed in pomegranate juice after 39 days compared to orange juice. The higher ascorbic acid concentration in orange juice (Table 2) may also aid Bifidobacteria survival. Ascorbic acid is an oxygen scavenger (Janjarasskul et al., 2013) and helps promote anaerobic conditions which are ideal for Bifidobacteria growth and survival. This could account for better survival of Bifidobacteria in orange juice as these cells are known to be very sensitive to oxygen. In addition, pomegranate juice contains a high amount of polyphenolic compounds which have antioxidant and anti-microbial properties (Al-Zoreky, 2009; Chidambara Murthy et al., 2002; Johanningsmeier and Harris, 2011).

This experiment showed that orange juice has more potential as a vehicle for the delivery of probiotics compared to pomegranate juice. However, the addition of probiotics to pomegranate juice will help increase its present therapeutic 
benefits, as it is known to contain several beneficial constituents including ellagic acid, punicic acid, flavonoids, anthocyanidins, anthocyanin, estrogenic flavonols and flavones (Devi et al., 2011). Thus, more research should be focused on the development of advanced technology to improve the survival of probiotics in pomegranate juice. One means of doing this could be combining $\gamma$-PGA with other biocompatible polymers such as polyglycerol sebactae (PGS) (Delete).

Apart from storage, another concern with regards to probiotic delivery is the survival of the bacteria during gastrointestinal tract transit where they encounter the gastric juice in the stomach as well as bile in the small intestine. A large reduction in viability of probiotic bacteria has been demonstrated in the stomach, a region of high acidity (Cui et al., 2000; Su et al., 2011; Vasiljevic and Shah, 2008). This study also found that free Bifidobacterium cells (B. longum and B. breve) died immediately with a $5 \log \mathrm{CFU} / \mathrm{ml}$ reduction in cell concentration within $1 \mathrm{hr}$ of incubation in simulated gastric juice and had reduced to undetectable levels within $2 \mathrm{hrs}$. Since $\gamma$-PGA is stable in acidic environments, and disintegrates in weaker acidic or neutral environments (Ho et al., 2006), it is a potential vehicle for the delivery of viable probiotic cells through the stomach environment. Results obtained from our experiment indicated that both $\gamma$-PGAimmobilised B. longum and B. breve cells showed marginal or no loss in viable cell concentration over a 4 hrs period of incubation in simulated gastric juice.

A comparison of $\gamma$-PGA protection of Bifidobacterium cells to other approaches such as alginate-human like collagen, alginate-poly-l-lysine and milk chocolate (Cui et al., 2000; Khalf et al., 2010; Possemiers et al., 2010; Su et al., 2011) in 
simulated gastric juice (Table 4) shows that $\gamma$-PGA could offer better protection to probiotic cells in gastric juice. The protection is possibly due to the fact that $\gamma$ PGA remains structurally stable in a low $\mathrm{pH}$ environment and disintegrates as the pH increases to above 6 (Ho et al., 2006) thus providing protection to cells from the highly acidic environment. In a pH stability study (Ho et al., 2006), strong intra-molecular hydrogen bonding existed in $\gamma$-PGA at $\mathrm{pH} 2.0$, as at that $\mathrm{pH}$ it formed a stable compact $\alpha$-helix conformation. When the $\mathrm{pH}$ was increased to 4.09 about $50 \%$ of the insoluble $\alpha$-helix conformations transformed into a linear random-coil conformation. At $\mathrm{pH}$ 6.0, all the intra-molecular hydrogen bonding was disrupted and a complete change in conformation was seen from $\alpha$-helix to random-coils (Delete). This property of $\gamma$-PGA is possibly useful for protecting probiotic bacteria in highly acidic gastric juice environment ( $\mathrm{pH} 2.0$ ). Moreover, and importantly for the intestinal delivery of probiotics, as $\gamma$-PGA reaches the intestine $(\mathrm{pH} \sim 6.0-6.5)$ the polymer should disintegrate because of the disruption of hydrogen bonds (Ho et al., 2006) leading to the release of the bacteria into the target site.

\section{CONCLUSIONS}

This research has shown that $\gamma$-PGA can be successfully used to immobilise probiotic Bifidobacterium strains and improve their survival during storage in acidic fruit juices, such as orange and pomegranate juice. This offers the opportunity to use fruit juices as alternatives to dairy products for probiotic 
1 delivery. This would be particularly beneficial for individuals who are lactose intolerant or are allergic to milk proteins, as dairy products are presently the major sources for probiotic delivery. In addition, $\gamma$-PGA can potentially protect Bifidobacterium strains against the acidic conditions of the stomach during gastrointestinal tract passage. This study, along with our previous work, suggests that $\gamma$-PGA could potentially be used as a single protective agent for probiotic bacteria during freeze drying, storage in fruit juices and during transit through the gastrointestinal tract.

Future work must include the protection of probiotic cells by $\gamma$-PGA in bile salt as well as their release in the intestine and subsequent colonisation of the host. Thus $\gamma$-PGA could have the potential to facilitate the effective delivery of sufficient numbers of viable probiotic bacteria to the gastrointestinal target sites leading to successful colonisation, which is important for delivering beneficial health effects (Delete).

\section{ACKNOWLEDGMENTS}

The authors will like to thank the University of Wolverhampton, Faculty of Science and Engineering for their financial support and granting access to their 


\section{REFERENCES}

Al-Zoreky, N.S., 2009. Antimicrobial activity of pomegranate (Punica granatum L.) fruit peels. International Journal of Food Microbiology 134, 244-248.

Allaker, R.P., Douglas, C.W.I., 2009. Novel anti-microbial therapies for dental plaquerelated diseases. International Journal of Antimicrobial Agents 33, 8-13.

Anal, A., Singh, H., 2007. Recent advances in microencapsulation of probiotics for industrial applications and targeted delivery. Trends in Food Science and Technology 18, 240-251.

Bertazzoni, E., Donelli, G., Midtvedt, T., Nicoli, J., Sanz, Y., 2013. Probiotics and clinical effects: is the number what counts? Journal of Chemotherapy 25, 193-212.

Bhat, A., Irorere, V., Bartlett, T., Hill, D., Kedia, G., Morris, M., Charalampopoulos, D., Radecka, I., 2013. Bacillus subtilis natto: a non-toxic source of poly- $\gamma$-glutamic acid that could be used as a cryoprotectant for probiotic bacteria. AMB Express 3, 1-9.

Burgain, J., Gaiani, C., Linder, M., Scher, J., 2011. Encapsulation of probiotic living cells: From laboratory scale to industrial applications. Journal of Food Engineering 104, 467-483. Cani, P.D., Delzenne, N.M., 2009. Interplay between obesity and associated metabolic disorders: new insights into the gut microbiota. Current Opinion in Pharmacology 9, 737 743.

Chandramouli, V., Kailasapathy, K., Peiris, P., Jones, M., 2004. An improved method of microencapsulation and its evaluation to protect Lactobacillus spp. in simulated gastric conditions. Journal of Microbiological Methods 56, 27-35.

Chidambara Murthy, K.N., Jayaprakasha, G.K., Singh, R.P., 2002. Studies on Antioxidant Activity of Pomegranate (Punica granatum) Peel Extract Using in Vivo Models. Journal of Agricultural and Food Chemistry 50, 4791-4795. 
Cui, J.H., Goh, J.S., Kim, P.H., Choi, S.K., Lee, B.J., 2000. Survival and stability of Bifidobacteria loaded in alginate poly-l-lysine microparticles. International Journal of Pharmaceutics 210, 51-59.

Devi, A., Singh, V., Bhatt, A., 2011. Comparative antibacterial study of different extract of pomegranate and its wild variety. International Journal of Pharmaceutical Sciences and Researsch 2, 2647-2650.

7 Ding, W., Shah, N., 2008. Survival of free and microencapsulated probiotic bacteria in orange and apple juices. International Food Research Journal 15, 219-232.

9 Doleyres, Y., Lacroix, C., 2005. Cell Immobilization For The Dairy Industry. Swiss Federal 10 Institute Of Technology, Switzerland. Fooks, L.J., Gibson, G.R., 2002. Probiotics as modulators of the gut flora. British Journal of Nutrition 88 Suppl 1, S39-49.

Granato, D., Branco, G., Nazzaro, F., Cruz, A., Faria, J., 2010. Functional foods and nondairy probiotic food development: trends, concepts, and products. Comprehensive Reviews in Food Science and Food Safety 9, 292-302. microencapsulated Bifidobacterium spp. in milk and simulated gastrointestinal conditions. Food Microbiology 19, 35-45.

Ho, G.H., Ho, T.I., Hsieh, K.H., Su, Y.C., Line, P.Y., Yang, J., Yang, K.H., Yang, S.C., 2006. $\gamma$-polyglutamic acid produced by Bacillus subtilis (natto) : Structural characteristics, chemical properties and biological functionalities. Journal of the Chinese Chemical Society 53, 1363-1384.

Johanningsmeier, S., Harris, G., 2011. Pomegranate as a functional food and nutraceutical source. Annual Reviews of Food Science and Technology 2, 181-201.

Kailasapathy, K., 2002. Microencapsulation of probiotic bacteria: technology and potential applications. Current issues in intestinal microbiology 3, 39-48.

Kailasapathy, K., Chin, J., 2000. Survival and therapeutic potential of probiotic organisms with reference to Lactobacillus acidophilus and Bifidobacterium spp. Immunology and Cell Biology 78, 80-88.

Kedia, G., Hill, D., Hill, R., Radecka, I., 2010. Production of poly- $\gamma$-glutamic acid by Bacillus subtilis and Bacillus licheniformis with different growth media. Journal of Nanoscience and Nanotechnology 10, 1-9.

Khalf, M., Dabour, N., Kheadr, E., Fliss, I., 2010. Viability of probiotic bacteria in maple sap products under storage and gastrointestinal conditions. Bioresource Technology 101, 7966-7972.

Krasaekoopt, W., Bhandari, B., Deeth, H., 2004. The influence of coating materials on some properties of alginate beads and survivability of microencapsulated probiotic bacteria. International Dairy Journal 14, 737-743.

Kurmann, J., Rasic, J., 1991. Therapeutic properties of fermented milks. Elsevier Science Publishers Ltd, London.

Lee, K.Y., Heo, T.R., 2000. Survival of Bifidobacterium longum immobilized in calcium alginate beads in simulated gastric juices and bile salt solution. Applied and Environmental Microbiology 66, 869-873.

Lozinsky, V.I., Galaev, I.Y., Plieva, F.M., Savina, I.N., Jungvid, H., Mattiasson, B., 2003. Polymeric cryogels as promising materials of biotechnological interest. Trends in Biotechnology 21, 445-451.

McFarland, L.V., Dublin, S., 2008. Meta-analysis of probiotics for the treatment of irritable bowel syndrome. World Journal Of Gastroenterology: WJG 14, 2650-2661.

Mortazavian, A., Azizi, A., Ehsani, M., Razavi, S., Mousavi, S., Sohrabvandi, S., Reinheimer, J., 2008. Survival of encapsulated probiotic bacteria in Iranian yogurt drink (Doogh) after the product exposure to simulated gastrointestinal conditions. Milchwissenschaft 63, 427-429.

Nualkaekul, S., Charalampopoulos, D., 2011. Survival of Lactobacillus plantarum in model solutions and fruit juices. International Journal of Food Microbiology 146, 111-117. 
Nualkaekul, S., Cook, M.T., Khutoryanskiy, V.V., Charalampopoulos, D., 2013. Influence of encapsulation and coating materials on the survival of Lactobacillus plantarum and Bifidobacterium longum in fruit juices. Food Research International 53, 304 -311.

Nualkaekul, S., Salmeron, I., Charalampopoulos, D., 2011. Investigation of the factors influencing the survival of Bifidobacterium longum in model acidic solutions and fruit juices. Food Chemistry 129, 1037-1044.

Patel, S., Goyal, A., 2013. Evolving Roles of Probiotics in Cancer Prophylaxis and Therapy. Probiotics and Antimicrobial Proteins 5, 59-67.

Possemiers, S., Marzorati, M., Verstraete, W., Van de Wiele, T., 2010. Bacteria and chocolate: A successful combination for probiotic delivery. International Journal of Food Microbiology 141, 97-103.

Prakash, S., Tomaro-Duchesneau, C., Saha, S., Cantor, A., 2011. The gut microbiota and human health with an emphasis on the use of microencapsulated bacterial cells. Journal of Biomedicine and Biotechnology, 1-12.

Reid, G., Jass, J., Sebulsky, M.T., McCormick, J.K., 2003. Potential uses of Probiotics in clinical practice. Clinical Microbiology Reviews 16, 658 -+.

Russell, D.A., Ross, R.P., Fitzgerald, G.F., Stanton, C., 2011. Metabolic activities and probiotic potential of bifidobacteria. International Journal of Food Microbiology 149, 88 105.

Saarela, M., Alakomi, H.L., Mättö, J., Ahonen, A.M., Puhakka, A., Tynkkynen, S., 2011. Improving the storage stability of Bifidobacterium breve in low $\mathrm{pH}$ fruit juice. International Journal of Food Microbiology 149, 106-110.

Saarela, M., Virkajärvi, I., Alakomi, H.-L., Sigvart-Mattila, P., Mättö, J., 2006. Stability and functionality of freeze-dried probiotic Bifidobacterium cells during storage in juice and milk. International Dairy Journal 16, 1477-1482.

Saarela, M., Virkajärvi, I., Alakomi, H., Mattila-Sandholm, T., Vaari, A., Suomalainen, T., Mättö, J., 2005. Influence of fermentation time, cryoprotectant and neutralization of cell concentrate on freeze-drying survival, storage stability, and acid and bile exposure of Bifidobacterium animalis ssp. lactis cells produced without milk-based ingredients. Journal of Applied Microbiology 99, 1330-1339.

Sánchez, B., Champomier-Vergès, M.-C., Collado, M.d.C., Anglade, P., Baraige, F., Sanz, Y., de los Reyes-Gavilán, C.G., Margolles, A., Zagorec, M., 2007. Low-pH Adaptation and the Acid Tolerance Response of Bifidobacterium longum Biotype longum. Applied and Environmental Microbiology 73, 6450-6459.

Sanchez, B., Champomier-Verges, M.C., Anglade, P., Baraige, F., de Los Reyes-Gavilan, C.G., Margolles, A., Zagorec, M., 2005. Proteomic analysis of global changes in protein expression during bile salt exposure of Bifidobacterium longum NCIMB 8809. J Bacteriol 187, 5799-5808.

Shah, N.P., Dave, R., 2002. Antimicrobial Substances Including Bacteriocins Produced by Lactic Acid Bacteria. Bioscience and Microflora 21, 217-223.

Shyu, Y., Sung, W., 2010. Improving the emulsion stability of sponge cake by the addition of $\gamma$-polyglutamic acid. Journal of Marine Science and Technology 18, 895-900.

Su, R., Zhu, X.L., Fan, D.D., Mi, Y., Yang, C.Y., Jia, X., 2011. Encapsulation of probiotic Bifidobacterium longum BIOMA 5920 with alginate-human-like collagen and evaluation of survival in simulated gastrointestinal conditions. International Journal of Biological Macromolecules 49, 979-984.

Theodorakopoulou, M., Perros, E., Giamarellos-Bourboulis, E.J., Dimopoulos, G., 2013. Controversies in the management of the critically ill: the role of probiotics. International Journal of Antimicrobial Agents 42, Supplement 1, S41-S44.

Turnbaugh, P., Ley, R., Hamady, M., Fraser-Liggett, C., Knight, R., Gordon, J., 2007. The human microbiome project. Nature 449, 804-810.

Vasiljevic, T., Shah, N.P., 2008. Probiotics-From Metchnikoff to bioactives. International Dairy Journal 18, 714-728.

Vidhyalakshmi, R., Bhakyaraj, R., Subhasree, R., 2009. Encapsulation "The future of probiotics"-A review. Advances in Biological Research 3, 96-103. 
